\title{
Discursive-Pragmatic and Translation Features of the Semantic Situation of Apology in Linguocultures
}

\author{
Anastasiya S. Dubovik* \\ Krasnoyarsk State Pedagogical University \\ named after V.P. Astafiev \\ 89 A. Lebedeva Str., Krasnoyarsk, 660049, Russia
}

Received 22.09.2015, received in revised form 10.10.2015, accepted 10.12.2015

\begin{abstract}
Formulas of apology are widely used in communication systems in many socio-cultural communities as a means of realizing the crucial social function that ensures the maintenance of harmony of interpersonal relationships between the participants of a communicative act. However, so far a number of problems associated with the peculiarities of the functioning of the formulas of apology in speech have not been studied yet, including the problem of the use of language units with the semantics of apology for the realization of other speech acts and formulas, as well as the problem of translation of the formulas used in the semantic situation of apology in general and translation of the formulas used in the British culture from English to Russian in particular. A traditional linguistic analysis, aimed at studying isolated linguistic forms, as a rule, does not take into account its closest context environment, conditions of use, as well as culturally-based interactive parameters, and as a result, can not determine the actual communicative value of this formula in natural interaction. In this paper, the author describes the functioning of the semantic situation of apology from the standpoint of discursive-pragmatic analysis, taking into account the extra-linguistic parameters of the situation of communication.
\end{abstract}

Keywords: the speech act of apology, the semantic situation of apology, the communicative situation of apology, linguocultures, etiquette rules, translation problems.

DOI: 10.17516/1997-1370-2015-8-12-2833-2841.

Research area: philology.

\section{Introduction}

At the present stage of development linguistics is characterized by an increased interest in the problem of language and culture. The science about language becomes the science about man, about his mentality and methods of his interaction with the environment and with other people. Numerous comparative studies show that people of different cultures do not always behave in the same way when they apologize, and the speech act has a number of cultural specific features. In this study, we attempted to identify common and idioethnic means of objectification of the category of

(C) Siberian Federal University. All rights reserved

* Corresponding author E-mail address: sphynx_08@list.ru 
apology in Russian and English linguistic cultures.

Apologies are referred to situations of varying degrees of importance - from usual tongue-slips and unintentional collisions in the crowd to international conflicts. A comparison of British and Russian apologies identified some differences concerning speech patterns, their semantics, expressiveness extent, frequency and situations of using. The English language offers several fixed apology formulas: (I'm) sorry / Excuse me / Pardon (Ibeg your pardon), as well as the formulas with apology, apologies, apologize, regret: I owe you an apology / Please accept my apologies / 1 do apologize for ... / I (We) regret .... In the situations where a slight breach of etiquette occurs, conventional apologies are used; this may be one minimal formula of apology (Sorry, I beg your pardon, My fault and in Russian извини(те), прости(те), виноват and others), but their combination may be extended if a person is morally hurt and it can be corrected. Thus, in the comparable communicative cultures, the cases when one is expected to apologize are treated differently: Russian people apologize if there is a reason to apologize, while the British do it more often and even in the situations where there is no obvious reason to. The Russian linguistic culture does not accept apologies to subordinates, so the apology of senior speakers are politely marked while in the English linguistic culture an apology made by a senior speaker to a subordinate only increases the prestige of the one who makes (Olshtain, 1989). An apology in Russian culture is not considered a noble gesture, it is rather perceived as admission of the speaker's guilt. In a public situation of apology pragmatic components acquire a significant role: it is important, who apologizes, in what context and in the presence of what audience, the text of the apology itself is also essential. That is why it is necessary to analyze not only the formula of apology, but the very semantic situation, its discursive-pragmatic characteristics to have a better understanding of the essence of apology.

\section{Conventional differences}

\section{of the semantic situation of apology}

in Russian and English linguocultures

An apology is traditionally referred to a variety of etiquette communicative acts aimed at maintaining or restoring the harmony of interpersonal relationships, intentionally or unintentionally disturbed during social activities (Rathmayr, 2003; Risinzon, 2010; Formanovskaya, 2009; et al.). The works of Russian researchers stress that apology performs an etiquette function, namely it adjusts social and ethical relations and is realized by the language means of the homonymous speech genre (Risinzon, 2010; Shevchenko, 2009; Shmeleva, 1997), but despite the theoretical justification of the place and the importance of apology as a unit of speech etiquette in general, the issues about the specificity of conventionality of its use by an English-speaking person in communicative practice are still a problematic field. The identification of the communicative act of apology as an object of observation (Austin, 1971; Coulmas, 1981; Searle, 1969) allows us to consider it "a procedural unit of communicative behavior, expressing socioculturally conditioned and linguoculturally actualized sense" (Mityagina, 2008). We shall note that many scientists who study linguopragmatic features of the speech act of apology tend to refer it to the statements expressing psychological states. John Searle in his classification of speech acts allocates a group of expressives with illocutionary force "to express the psychological state with respect to the propositional content of the statement" including expressives sorry, pity in it (Searle, 1986). L.A. Piotrovskaya after A. Wierzbicka (Wierzbicka, 1987) points out that these 
expressives can not only express but also describe psychological states (Piotrovskaya, 2009). It should be noted that the statements with the pragmatic seme of apology in certain situations do express emotions experienced by the speaker at the moment of speaking, or evaluate them through the description of feelings, but there are some more functions of apology - in particular, in the British communicative culture apology is also a formal method to regulate relations.

\section{Some scenarios}

\section{of the communicative situation of apology}

The performative nature of apology is beyond doubt. It affects interpersonal relationships of participants of communication, changing their correlative status and future state. When pronouncing an apology, according to R. Lakoff, the speaker (addressant): 1) recognizes that did something bad; 2) recognizes that the addressee is affected; 3) expresses the need in being forgiven by the addressee to restore the normal situation (Lakoff, 2007). In general, this behavior is stereotyped and can be represented by this scenario of the communicative situation of apology: "wrong behavior - apology - agreement to accept an apology/minimization of the damage" forming a microdialogue or a part of a dialogue with a specific priority that can be broken, i.e. it is a conscious deviation from the usage (Coulmas, 1981). Stereotyping is obviously shaped by social conventions prescribing to denote the realization of one's misconduct by means of the speech act in the case of intentional or unintentional violation of the rules of politeness. In case of a situationscenario approach to apology, a special attention should be paid to the issue of presupposition and variability of the motives of its actualization in the English-speaking culture.

Our analysis of the motives of actualization of apology in the British communicative culture allowed distinguishing two kinds of scenarios of the communicative situation of apology, which differ in the motives and degree of conditionality. They are real apologies which demonstrate repentance and admission of guilt, and formal, which are related to a significant number of violations of etiquette conventions and social distance breaking and are not connected with emotional experiences. We have considered the differences between the two scenarios of apology according to the parameters of intentions and emotional involvement of participants.

The presupposition of the communicative situation of "real apology" involves the appearance of guilt felt by one of the participants, who realizes that his actions (verbal or non-verbal) are harmful to the other person, experiences the emotion of shame, pleads himself guilty, and with the help of a speech act of apology requests to remove his guilt (Rathmayr, 2003). In accordance with the etiquette expectations the other person (the addressee) recognizes the intention of the addressant and either accepts or rejects the apology. The described scenario reflects the duality of the psychological state of the speaker: on the one hand, the apology is based on a sense of guilt and shame, and on the other hand - on the intention to get rid of experiences by encouraging the addressee to forgive. The purpose of the communicative act of apology is seen as reaching "the changes in the psychological tone of the relationship with the addressee in accordance with the interests of the speaker: apologizing, he intends to restore / maintain the friendly tone of communication" (Shevchenko, 2009). The remarkable thing is that we deliberately do not call such an apology sincere, as the speaker may have different intentions, for example, an apology may be insincere, but its speech form will fully comply with the ritual of a sincere one (Tolkacheva, 2009; Plotnikova, 2000).

Wehaveconsidered themethods of expressing real apologies in the British communicative 
culture. As a rule, the signal of the speech act of "apology" is a standard etiquette phrase I am sorry, that is aimed at restoring the harmony of interpersonal relationships; the awareness of the fact of violation of moral and ethical norms, the convention of sincerity and honesty is often accompanied by the demonstration of the corresponding emotions, usually they are the emotions of shame and repentance. The one who makes a real apology is aware of the fact that the addressee is angry or hurt, or at least, the addressant has a reason to fear that, therefore, he asks the addressee to stop experiencing negative emotions, a speech set becomes longer, he repeats the formulas of apology, including the emotional and evaluative markers which intensify emotions (e.g., very, awfully, honestly, terribly, etc.). It is significant that in this case it is only about one kind of the communicative act of apology, which is called a real apology or "an essential apology" in our study after R. Rathmayr (Sapir, 1993). It can be defined as a form of "expressive speech behavior with the function of restoring social balance or harmony of relations between communicants" (Ilinova, 2012), it is characterized by a high degree of emotional involvement of the person initiating the act of apology as "the emotion of shame is related to the emotionally evaluative attitude of the person to their own actions "(Izard, 2002), the person's emotional stress is caused by self-condemnation that in a perfect world should be accompanied by communicative actions of repentance and belittling one's own status. The intention to ask for forgiveness is realized in a real apology, and the addressee is necessarily required to show his personal reaction that is either the consent to accept an apology or the reject which may be represented in a verbal or nonverbal way (e.g., delayed response, silence).

The presupposition of the communicative situation of "formal apology" determines the realization of preventive and corrective scenarios that are actualized in other circumstances of interpersonal communication, particularly in Anglophone society they become a tool of rapprochement in the case of imminent and/or accidental violation of personal space of another person (in the literal or metaphorical sense). In this case, it refers to the conventional violation of the demonstration of respect, attention, attentiveness to any person in any situation via communicative distancing that is called good manners and courtesy in the English communicative culture (Larina, 2009).

The rules of etiquette make the British constantly appeal to formalized apologies that do not relate to the pragmatics of shame and real admission of guilt. When a person realizes the inevitability of physical contact with another person in the case of movement in space (e.g., when it is necessary to pass a street walker or to pass very close) or other intrusion into the personal space of a stranger or an unfamiliar person, the act of preventive apology is obligatory (Excuse me! How could I get to ... ? / I beg your pardon. Would you mind my taking this thing?). At the same time the speaker does not feel repentance, does not look for protection, but with the help of a formal apology he justifies his future action. In the case of a collision in the street or inside a building or doing a minor (unexpected, but inevitable) damage, the convention of politeness requires to realize the scenario of a corrective apology, in which a response replica that should minimize the emerged sense of discomfort is possible.

It can be concluded that the communicative scenario of apology both in Russian and British linguocultures is based on the speaker's awareness of any deviation from the rules of etiquette and politeness that is regarded as a violation of the conventions of distancing and unimpositiveness in the British communicative culture. The pragmatics of apology depends on 
a combination of conditions that accompany the actualization of the speech act in order to restore an imbalance of interpersonal relationships, and is manifested in the selective expertise. In spite of a small and very typed number of means of realizing an apology in the English language, its relevance can be attributed to different purposes and reasons that allows separating real and formal apologies, which, in turn, vary in nature and the degree of violation of social conventions (moral and ethical conventions, the conventions of physical, psycho-emotional and communicative distancing) and the place of the speech act of apology in the scenario.

\section{The problems of translation}

of the formulas of apology of the British language culture into the Russian language.

\section{Conclusion}

In most studies, which describe the use of the formulas of apology in speech, these language formulas are seen only as the means of realization of the speech act of apology by scientists (Coulmas, 1981; Edmonson 1981; Meier, 1998; Rathmayr, 2003; and many others). However, a huge number of problems associated with the peculiarities of the existence of these formulas in speech have not been studied yet, including the problem of the use of language units with the semantics of apology to realize other speech acts. A traditional linguistic analysis, which aims at studying a single language formula, usually does not take into account its nearest context environment, conditions and socio-cultural specificity of use and, as a result, does not identify the real communicative value of this formula in natural communicative environment. Meanwhile, the linguistic forms with the semantics of apology are widely used in English-speaking cultures to express the meanings which are not directly related to apology, such as regret, sympathy, condolences, outrage and others. It is commonly known that the cultural specificity of the semantic systems of different languages is the reason why even the presence of lexical universals does mean an absolute equivalence in the language use, as well as why many structures can not be translated from one language into another - in our study from English into Russian - without a significant loss.

Speaking about the problems of translation, it is appropriate to mention symmetry/asymmetry in the original text and the translation itself as one of the first theories about the difficulties of translation. Symmetry/asymmetry of translation can be traced at the level of phonetic, morphological, lexical and syntactic units of language structures that was marked in one of the first fundamental works on the linguistic theory of translation in the monograph of Georges Mounin. There are no fully symmetric or asymmetric original texts and their translations. The ratio, the proportions of symmetric and asymmetric elements and structures in the original and in the translation result in a certain quality of translation (Razumovskaya, 2011).

In the course of our review of modern British literature and several translations of the originals into the Russian language for the study of the semantic aspect of the formulas of apologies and socio-cultural specificity of the situations we could make the following conclusions:

1) The formulas of apology do not always serve as a means of expressing an apology in a real dialogue. The communicative value realized by these forms in the discourse is determined by the conditions of success of the speech acts, by means of which they are realized.

2) The English language formulas with the semantics of apology in real communication are used to realize not only a speech act of apology, but such diverse speech acts as the acts of regret, sympathy, condolences, an echo-question / a request to repeat or clarify the previous phrase, 
setting a communicative contact, ending a communicative contact, "cutting into" the conversation, and others. These speech acts have different characteristics; they are the means to achieve different illocutionary goals and are used in different communication circumstances. In this regard, the identified and adequate description of the functioning of the formulas of apology in speech involves the analysis of the pragmatic conditions on corresponding speech acts and contexts of their realization (Pletneva, 2009).

3) The essence of the speech act of apology is in the fact that apology is a socially meaningful expressive speech action, aimed at achieving or restoring social harmony, the need in which appears in the violation of the norms of cooperative interaction. The necessary conditions for the successful realization of the speech act of apology are: the presence of damage done by the speaker to the addressee, the speaker's awareness of responsibility for what happened, the psychological discomfort he feels, as well as a desire to restore communicative harmony.

4) Among all the English formulas with the semantics of apology in the British linguoculture only the forms (I am) Sorry, Forgive me and I apologise / (My / Our) Apologies are used to realize the actual speech act of apology. Exactly these formulas, used in the British culture to express an apology, often keep the meaning of apology even in the translation into Russian. Such formulas of apology as Excuse me and Pardon (me) / 1 beg your pardon are the conventional means to express other speech acts.

5) The formulas with the semantics of apology (I am) Sorry, Excuse me, Forgive me, I apologise / (My / Our) Apologies, Pardon (me) / 1 beg your pardon can not be used in different types of communicative situations as synonymous and interchangeable, because, in accordance with the conventions of the use existing in Englishspeaking cultures each of these formulas has its own communicative meaning and the scope of use. This functioning of the formulas of apology in speech reflects the asymmetrical relations between the form and the content in the language.

The study of the functioning of the speech formulas with the semantics of apology in question such as (I am) Sorry, Excuse me, Forgive me, I apologize / (My/Our) apologies, Pardon (me) / 1 beg your pardon shows that these formulas are used only in strictly fixed communication situations and are not interchangeable. The functioning of these formulas of apology in the discourse reflects the lack of a direct relation between the semantic content of the form and the communicative meaning expressed by it. In accordance with the conventions of the use and external social attitudes existing in Englishspeaking cultures each of these formulas has developed its own conventional value that is only indirectly motivated by the language semantics.

Thus, apology, despite the seeming simplicity of this phenomenon, is quite a difficult thing to analyze. A particular attention is required for literary translation of formulas of apology from English into Russian. Despite a considerable progress in the study of literary translation, the issue of a comprehensive study of different aspects of the formulas of apology in the discourse of event, as well as the definition and description of the distinguishing features of the functioning of the described conventional formulas to express other communication functions within real dialogue is still understudied. The situation of apology is the most important to adjust the speech interaction between communicants, so the study of formulaic etiquette models of apology is relevant to maintain contact in crosscultural communication, restore social balance and preserve harmony between participants of verbal interaction (Moseiko, 2014). In this regard, the consideration of the common factors and the 
specific character of the use of the formulas of apology in speech involves a further analysis of the pragmatic conditions on corresponding speech acts and the contexts of their realization.

\section{References}

Austin, J. Philosophical and ordinary language. London: Cambridge University Press, 1971. $427 \mathrm{p}$.

Coulmas, F. Conversational Routine. Explorations in Standardized Communication Situations and Prepatterned Speech. The Hague, HPH, 1981. 331 p.

Edmondson, W.J. On saying you're sorry (in F. Coulmas (Ed.) Conversational routine: Explorations in Standardized Communication Situations and Prepatterned Speech). The Hague, Mouton, 1981. P. 273-288.

Formanovskaya, N.I. Speech Etiquette in Russian Communication [Rechevoi etiket v russkom obshchenii]. Moscow, VK, 2009. 333 p.

Ilinova, E.Yu. Normalization and pragmalinguistic features of apology in the English communicative culture [Normativnost i pragmalingvisticheskiye osobennosti izvineniia $v$ angliyskoi kommunikativnoi kulture, in Aktualnye problemy kommunikatsii i kultury]. Vol. 14. Part I. Moscow, Pyatigorsk, Pyatigorsk State Linguistic University, 2012. P. 159-165.

Izard, C. The Psychology of Emotions [Psihologiia emotsi]). St. Petersburg, Peter, 2002. 464 p.

Lakoff, R. The Pragmatics of Public Apology [Pragmatika publichnogo izvineniia]. Zhanry rechi: Sbornik nauchnykh statei. Vol. 5. Translated by V.V. Dementiev and E.B. Kovelyeva) Saratov, Nauka, 2007. P. 183-192.

Larina, T.V. The Category of Politeness and the Style of Communication: a comparison of British and Russian linguocultural traditions [Kategoriya vezhlivosti $i$ stil' kommunikatsii: sopostavlenie angliyskih i russkih lingvokulturnykh traditsii]. Moscow, Rukopisnye pamyatniki Drevney Rusi, 2009. $333 \mathrm{p}$.

Meier, A. (1998). Apologies: what do we know? International Journal of Applied Linguistics, 8 (2), 215-231.

Mityagina, V.A. (2008). The type of communicative action in discourse: verification within the genre [Tip kommunikativnogo deistviia v diskurse: verifikatsiia v ramkakh zhanra]. Vestnik of VolGU, Series 2, Linguistics), 116-119.

Moseiko, A.A. Etiquette model of apology in the British and Russian linguistic cultures [Etiketnaia model izvineniia v britanskoy i russkoy lingvokulturakh]. Series 5. Part II). Tambov, Gramota, 2014. P. 136-138.

Olshtain, E. Apologizes Across Language. Cross-Cultural Pragmatics: Requests and Apologies). Blum-Kulka, Sh., House, J. \& Kasper, G. (eds.). Norwood, N. J., Ablex, 1989. P. 155-173.

Piotrovskaya, L.A. "Language to description emotions" and "language to express emotions": a new solution to an old problem [«Yazyk opisaniia emotsii» $i$ «yazyk vyrazheniia emotsii»: novoe reshenie staroi problemy in Yazyk i emotsii: nominativnye i kommunikativnye aspekty]. Volgograd Scientific Publishing House, 2009. P. 74-85.

Pletneva, E.A. Communicative and pragmatic range of formulas of apology in the British language culture [Kommunikativno-pragmaticheskii diapazon formul izvineniia v britanskoi yazykovoi culture]. Voronezh State University, 2009. 20 p. 
Plotnikova, S.N. Insincere discourse (in the cognitive, structural and functional aspects) (Neiskrenniy diskurs (v kognitivnom i strukturno-funktsionalnom aspektakh). Irkutsk State Linguistic University Publishing House, 2000. 244 p.

Razumovskaya, V.A. Semantic situation and Semantic symmetry / asymmetry in translation [Semanticheskaia situatsiia i semanticheskaia simmetriia/ asimmetriia v perevode]. Aktualnye problemy perevodovedeniia. Materialy XL Mezhdunarodnoi filologicheskoy konferentsii). St-Petersburg State University, Philological Faculty, 2011. P. 122-127.

Rathmayr, R. The Pragmatics of Apology: a comparative study on the material of the Russian language and Russian culture [Pragmatika izvineniia: sravnitelnoe issledovaniie na materiale russkogo yazyka i russkoi kultury]. Moscow, Yazyki slavyanskoy kultury, 2003. 272 p.

Risinzon, S.A. General and ethno-cultural in English and Russian speech etiquette: Monograph [Obshchee i etnokulturnoye $v$ russkom i angliiskom rechevom etikete: monografia]. Saratov,Nauka, 2010. $420 \mathrm{p}$.

Searle, J. Speech acts. Cambridge University Press, 1969. 306 p.

Searle, J. A Classification of Illocutionary Acts [Klassifikatsiia illokutivnykh aktov]. [Novoe v zarubezhnoi lingvistike. Iss. XVII: Teoriya rechevykh aktov. Translated by V.Z. Demyankov]. Moscow, Progress, 1986. P. 170-194.

Sapir, E. The selected works on linguistics and culturology [Izbrannye trudy po yazykoznaniiu $i$ kulturologii]. Moscow, Progress, 1993. 656 p.

Shevchenko, I.S. The hybrid nature of apology: cognitive-pragmatic analysis [Gibridnaia priroda izvineniia: kognitivno-pragmaticheskii analiz]. [Zhanry rechi. Iss. 6. Zhanr i yazyk]. Saratov, Nauka, 2009. P. 329-336.

Shmeleva, T.V. The Model of Speech Genre [Model rechevogo zhanra]. [Zhanry rechi]. Saratov, College, 1997. 280 p.

Tolkacheva, T.I. Emotional-pragmatic component of communicative behavior in a situation of "Admission of guilt" (on the material of English prose) [Emotsionalno-pragmaticheskii component kommunikativnogo povedeniia v situatsii "Priznanie viny" (na materiale angloiazychnoi prozy)]. Volgograd, 2009. 227 p.

Wierzbicka, A. English Speech Act Verbs: A Semantic Dictionary. Sydney, Orlando, Academic Press, 1987. 397 p. 


\title{
Дискурсивно-прагматические \\ и переводческие особенности \\ семантической ситуации извинения \\ в лингвокультурах
}

А.С. Дубовик

Красноярский государственный педагогический университет

им. В.П. Астафьева

Россия, 660049, Красноярск, ул. А. Лебедевой, 89

\begin{abstract}
Формулы извинения широко используются в коммуникационных системах во многих соииокультурных сообществах, являясь средством реализации исключительно важной соииальной функиии, обеспечивающей поддержание гармонии межличностных отночений между участниками коммуникативного акта. Однако до сих пор не исследованным остается иельй ряд проблем, связанных с особенностями функиионирования формул извинения в речи, в том числе проблема использования языковых единии с семантикой извинения для реализации других речевых актов и формул, а также проблема перевода формул, применяемых в семантической ситуации извинения в общем, и перевода формул, используемых в британской культуре, с английского языка на русский в частности. Традиционный лингвистический анализ, направленный на изучение изолированной языковой формы, как правило, не принимает во внимание ее ближайтее контекстное окружение, условия употребления, а также культурно обусловленные интерактивные параметры, и, как следствие, не позволяет определить реальное коммуникативное значение этой формуль в естественной интеракиии. В данной статье автор описывает функиионирование семантической ситуации извинения с позиций дискурсивного-прагматического анализа и при учете экстралингвистических параметров ситуации общения.
\end{abstract}

Ключевые слова: речевой акт извинения, семантическая ситуация извинения, коммуникативная ситуачия извинения, лингвокультура, нормы этикета, проблемы перевода.

Научная специиальность: 10.00.00 - филологические науки. 